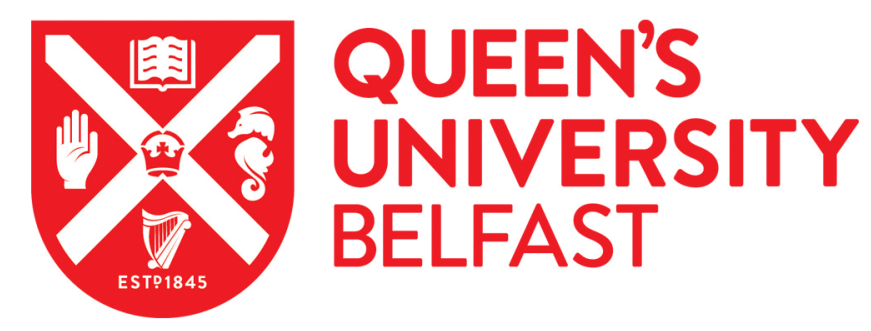

\title{
WE-H-BRA-07: Mechanistic Modelling of the Relative Biological Effectiveness of Heavy Charged Particles
}

McMahon, S., McNamara, A., Schuemann, J., Prise, K., \& Paganetti, H. (2016). WE-H-BRA-07: Mechanistic Modelling of the Relative Biological Effectiveness of Heavy Charged Particles. Medical Physics, $43(6), 3844$. https://doi.org/10.1118/1.4957998

\section{Published in:}

Medical Physics

\section{Document Version:}

Peer reviewed version

Queen's University Belfast - Research Portal:

Link to publication record in Queen's University Belfast Research Portal

\section{Publisher rights}

Copyright 2016 AAPM

This work is made available online in accordance with the publisher's policies. Please refer to any applicable terms of use of the publisher.

\section{General rights}

Copyright for the publications made accessible via the Queen's University Belfast Research Portal is retained by the author(s) and / or other copyright owners and it is a condition of accessing these publications that users recognise and abide by the legal requirements associated with these rights.

Take down policy

The Research Portal is Queen's institutional repository that provides access to Queen's research output. Every effort has been made to ensure that content in the Research Portal does not infringe any person's rights, or applicable UK laws. If you discover content in the Research Portal that you believe breaches copyright or violates any law, please contact openaccess@qub.ac.uk. 


\title{
WE-H-BRA-07: Mechanistic Modelling of the Relative Biological Effectiveness of Heavy Charged Particles
}

\author{
Authors: McMahon, S., McNamara, A., Schuemann, J., \\ and Paganetti, $\mathbf{H}$.
}

\section{Abstract}

Purpose Uncertainty in the Relative Biological Effectiveness (RBE) of heavy charged particles compared to photons remains one of the major uncertainties in particle therapy. As RBEs depend strongly on clinical variables such as tissue type, dose, and radiation quality, more accurate individualised models are needed to fully optimise treatments. MethodsWe have developed a model of DNA damage and repair following X-ray irradiation in a number of settings, incorporating mechanistic descriptions of DNA repair pathways, geometric effects on DNA repair, cell cycle effects and cell death. Our model has previously been shown to accurately predict a range of biological endpoints including chromosome aberrations, mutations, and cell death. This model was combined with nanodosimetric models of individual ion tracks to calculate the additional probability of lethal damage forming within a single track. These lethal damage probabilities can be used to predict survival and RBE for cells irradiated with ions of different Linear Energy Transfer (LET). ResultsBy combining the X-ray response model with nanodosimetry information, predictions of RBE can be made without cell-line specific fitting. The model's RBE predictions were found to agree well with empirical proton RBE models (Mean absolute difference between models of $1.9 \%$ and $1.8 \%$ for cells with $\alpha / \beta$ ratios of 9 and 1.4 , respectively, for LETs between 0 and 15 $\mathrm{keV} / \mu \mathrm{m})$. The model also accurately recovers the impact of high-LET carbon ion exposures, showing both the reduced efficacy of ions at extremely high LET, as well as the impact of defects in non-homologous end joining on RBE values in Chinese Hamster Ovary cells.ConclusionOur model is predicts RBE without the inclusion of empirical LET fitting parameters for a range of experimental conditions. This approach has the potential to deliver improved personalisation of particle therapy, with future developments allowing for the calculation of individualised RBEs.

SJM is supported by a Marie Curie International Outgoing Fellowship from the European Commission's FP7 program (EC FP7 MC-IOF-623630) 